UDK 453.11.978

DOI: 10.36550/2415-7988-2020-1-189-139-142

LYSENKO Liudmyla Oleksandrivna -

$\mathrm{PhD}$, Associate Professor, Chair of Linguodidactics And Foreign Languages Volodymyr Vynnychenko Central Ukrainian State Pedagogical University ORCID: https://orcid.org/0000-0001-5732-6317 e-mail: lysenkoluda78@i.ua

\title{
DEVELOPING NEW APPROACHES FOR IMPROVING CLASSROOM ACTIVITIES
}

Formulation and justification of the relevance of the problem. Learning foreign languages seems to become more and more increasing requirement of modern education. Issue of effective teaching methods have always been widely discussed in educational world community as finding the effective ones is the task of primary importance. One of the main distinctive features of today's education system is moving of gravitation center from the traditional methodology of conducting lessons to innovational one. This process is usually accompanied with a series of obstacles that do not leave the teaching and learning process unmarked. Technology classroom activities differ greatly from the traditional ones. The teacher should take into account various methodological, psychological, linguistic and physical aspects that impact the process of learning of foreign language. Designing and implementing technologies in the teaching and learning process has become one the most demanding tasks in modern education.

Analysis of the recent researches and publications. Problems devoted to introducing of new technologies in the teaching and learning process of foreign language are the issues of the research of many foreign researchers as G. Dudeney and N. Hockly, J. Harmer. G. Dudeney emphasizes that a layout which has computers at desks around the walls, facing the walls, with a large table in the center of the room, allows the teacher to walk around and easily see what the learners are working on and what they're looking at on the computer screens (monitors). The central area provides and easily accessible space where learners can go when they don't need the computers, and for when they might want to do some communicative group work [4, p. 13-14].

Speaking about language laboratories, J. Harmer stresses the role of innovation overuse that makes teaching and learning too machinebased. This allows teachers and students to listen, word process, watch video clips or other presentation programs. Teachers can have students work individually, individually with the teacher, in small groups or in lockstep where the whole class working with the same material at the same time. The great advantage is that users no longer have to worry about alphabetical order. They can find what they want just by typing in a word or phrase. Modern portable electronic dictionaries are now much more impressive than the originals since they have bigger windows, better navigation systems, and often two or more dictionaries bundled into the same device [6, p. 256-257].

It should be noted that, as language teachers we should make our classroom microcosms of life [2, 36 p.], with real relationships and purposeful use of language. All our techniques and technologies should be directed toward achieving this goal. So, it's upon a teacher how effective their ways of teaching might be in order to help students use the language we teach in their real life. We must keep in mind some very important things how to turn all the activities into interactive and really communicative.

The concept of interactive language teaching was developed by Brown H. D, W. Rivers and Michael Canale. W. Rivers (1987) states that through interaction, students can increase their language store as they listen to read 'authentic linguistic material', or even the output of their fellow students in discussions, joint problem-solving tasks, or dialogue journals.

The first thing to be mentioned is that education process is based on interactive language teaching. Students are no longer the objects to be installed and filled with different sorts of information. They should participate in the education process together with the teacher, not only acquire knowledge presented by the teacher, but they should also get it themselves from a deep well of knowledge and understanding using all possible techniques and technologies. So, in today's modern world, technology has an ever-changing effect on many things - and this includes English language learning and teaching. Technology has gained a more prominent place in classrooms in recent times and is of particular use to modern teachers.

The purpose of the article is to highlight the principal concepts of using effective technologies of learning English. Throughout the work we mention the importance of correct 
application of information communication technologies in teaching a foreign language and various factors which accompany that process and from which much depends.

The main material of the study. Technology, in one form or another, has always been part of the teaching and learning environment. It is part of the teacher's professional toolbox. In other words, it is among the resources that teachers use to help facilitate student learning. Technology has changed dramatically over recent decades. The increasing variety and accessibility of technology has expanded the toolbox and the opportunities teachers have to use technology. Computer devices are more powerful and come in different forms, from those that sit on our desks to those that sit in the palm of our hands. The internet connects those devices and connects students to each other in the classroom, through the school and around the world. Technological devices and networks have changed our schools and classrooms. Information technologies are the catalysts of the social progress. Their use in the sphere of education allows not just collecting, saving, processing, presenting and circulating of all information types but also contains vast opportunities for person-oriented education, promotes the selection of content, individualization, management programming of learning process, cognitive work of every student $[1$, p. 132]. Learning second language is a process as complex as second language teaching: various factors contribute to and combine together in order to achieve the success of this endeavour. To result in a favourable outcome, teachers have to devote a lot of time and effort to determine the most satisfactory, suitable and effective methods of teaching. Not only everyday reality is affected by the new technology, but also the development of language skills started to depend on it. As the number of English learners is ever increasing, fortunately, more and more modern tools and technology devices are implemented into the process of teaching. Currently, teachers tend to use tools such as videos, podcasts, worksheet banks, e-learning platforms, applications, and websites, accessible through electronic devices such as personal computers, or smart phones. These inventions facilitate classroom environment and diversify learning activities.

It is quite obvious that, a wide range of multimedia can be implemented to enhance the quality of education and boost the effectiveness of second language teaching. The boredom and the routine of using only a course book and repeatedly drilling the same types of exercises can be easily avoided.
While lectures and lessons can be informative when delivered with passion and good materials by knowledgeable experts, sadly many traditional lectures and lessons are boring, and even worse often ineffective. The good news is that the Web is loaded with great free tools that can enable teachers to bring a sense of fun and engagement to their lessons. Of course, you do need devices with Internet access to give these tools a try. Even if you don't have computers or tablets available in your classroom, the fact that an increasing number of students have smartphones is making it easier than ever to leverage technology to create engaging, active lessons students enjoy working on. Here's a whole bunch of ideas for leveraging technology to kick those lessons up a notch!

\section{Incorporate Student Input \& Gather}

\section{Feedback}

There are many applications that allow students to provide live feedback. A lot of them can be used from smartphones. You can also gather feedback by creating a «back channel» using Twitter.

- Quick, easy Polling Applications: PollDaddy and PollEverywhere are two of many applications that make it quick and easy to create simple polls that can let you gather feedback from students - determine if they are struggling with a topic, if they know the correct answers to questions you ask, and so on. They can often participate in these polls using a smartphone.

- Plickers: This is a pretty cool lo-tech approach to collecting student responses during class that doesn't require students to use technology.

- Twitter: Twitter is a great way to gather input by creating an easy to use 'backchannel'. This is great for students with smartphones (they will need the Twitter app and an account). Simply create a unique hashtag and have students post feedback to Twitter using that hashtag.

\section{Gamify It}

Leveraging gaming mechanics that can make learning more fun is probably easier than you think. Any time you bring competition or levels of achievement to a classroom exercise, you're adding an element of 'gamification'. Of course, gamification can be leveraged in much richer ways.

\section{Let Students Create}

There are so many fun free tools and apps available today that can let students create all kinds of awesome digital content. Below is diversified set of different article and resources that share different tools and ideas for students (and teachers) to create digital content presentations, interactive digital posters, eBooks, 
videos, and more. In the spirit of creating in the classroom, we also included an article introducing the burgeoning Makerspace Movement in education.

\section{Get Interactive}

Many teachers enjoy using interactive tools with their students. Here are a few tools and ideas to consider.

Online Interactive White Boards: Did you know that there are several good free interactive whiteboards available online? If you have a computer and a projector, you can make them work a lot like a «smart board». Some of these applications even allow students to log on online and collaboratively edit content.

- Interactive apps that work with Smartphones: Many of the tools in this article work on smartphones!

\section{Have Students Collaborate}

Getting students to work together as partners, in small groups, or maybe even as one large group, teaches them about team work. Collaborative work can be fun. It is even possible to collaborate with students across the world thanks to many of today's technologies. Here are a number of tools and techniques for classroom collaborations.

- Share writing and encourage feedback with News Activist: News Activist is a free tool that lets teachers set up their students with a private area where they can write about selected subjects. You can enables them to share what their write with just their classmates, or with the larger audience of students from across the world using NewsActivist. Students can then provide feedback on other students' writings.

- Collaborative Document Editing with Google Drive (drive.google.com): Google Drive lets you share and collaboratively edit Google Docs with anyone else who has a Google account, for free. This is a powerful capability.

- Collaborative Mind Mapping with MindMeister (mindmeister.com): This applications lets users easily create mind maps that can be edited collaboratively.

- Collaborative Research: Working in pairs or small groups to find, assess, summarize, and present content in specific topic areas make for a great learning experience and assignment.

\section{Project Based Learning}

When students apply what they are learning to projects that they undertake, the topics they are learning about can take on a much deeper meaning. Not only does the activity and the increased sensory exposure of project work help to stimulate the mind, the extended time often required of project work, and the visible, tangible results further reinforce learning.

\section{Simulations}

Simulations can be a powerful addition to the classroom. Since they tend to be somewhat complicated, they are typically suited towards high school, college, or post-graduate or professional studies. Here are some examples of simulations being used in education:

- Economics: This site, EconomicGames.com, offers free online classroom games for teaching economics.

- Marketing: Have you ever wished you could give your Marketing students the chance to practice different e-marketing skills and techniques? Check out Simbound.

- Medical: Simulations have been a significant teaching and learning tool in the medical field for many years. Harvard Medical School has even created a web site focused on their use of Simulations.

- Business: Business Simulation Games are a great way to bring active, applied learning into Business courses.

\section{Bring in a Guest or Two}

With the power of video conferencing apps like Skype, Google Hangout, Facetime, and others, our ability to connect with people all across the world has never been better or less costly. Teachers have been using Skype and similar tools to being guest lecturers, experts, students, and others into the classroom for years. Nothing breaks up the monotony of «same old thing» like an enthusiastic subject matter expert from another county or a room full of students from another continent!

Last but not least, modern technology in the classroom allows students to develop abilities needed in their future workplaces. They acquire practical skills such as research and critical thinking which are essential in the $21^{\text {st }}$ century.

Conclusions and prospects for further researches of direction. The media along with the emerging technology can be an excellent tool to teach a foreign language. The usage of such devices does not reject traditional methods or undermine their importance, but rather supports and completes the whole process of teaching and learning by offering alternative forms of spreading the knowledge and putting it into practice. With the help of activities involving multimedia, the classroom becomes more dynamic and interesting place which makes learning more efficient and pleasant. However, the implementation of such exercises depends on the presence of electronic devices in the classroom.

\section{BIBLIOGRAPHY}

1. Solanki D. Shyamlee, M Phil. Use of Technology in English Language Teaching and Learning: An Analysis / IACSIT Press, Singapore, 2012. vol 33 . 
2. Al-Mahrooqi R., Troudi S. Using Technology in Foreign Language Teaching / Cambridge Scholars Publishing, 2014.

3. Hossain R, Shaikh P., Salam F. The Effectiveness of Using Technology in English Language Classrooms in Government Primary Schools in Bangladesh / Issue 1 Information and Communication Technology (ICT) for Development Special Issue, 2015.

4. Shandruk, Svitlana. Tendentsii profesiinoi pidgotovky vchyteliv u USA [Tendencies of professional preparation of teachers in the USA] : [monography]. Kirovohrad:Imeks-LTD, 2012.

5. Tafani V. Teaching English Through Mass Media/ ActaDidacticaNapocensia, Volume 2 Number 1, 2009.

6. The Use of the Media in English Language Teaching / ELT documents / The British Council, 1979.

7. Webster R. A reflective and Participatory Methodology for E-learning and Life-long Learning / R. Webster // Advances in E-learning: Experiences and methodologies / J. Francisco, G. Penalvo // Information Science Reference. Hershey. 2008. P. 4.

8. Wilson B. What is a constructivist learning environment? In B. g. Wilson (Ed.) / B. Wilson // Constructivist learning environments: Case-studies in instructional design: Educational Technology Publications. 1996. P. 3.

\section{REFERENCES}

1. Solanki, D. Shyamlee, M Phil. (2012). Vy'kory'stannya texnologij u vy`kladanni ta navchanni anglijs 'koyi movy'. [Use of Technology in English Language Teaching and Learning].

2. Al-Mahrooqi, R., Troudi, S. (2014). Vykorystannya tekhnolohiy $u$ vykladanni inozemnykh mov. [Using Technology in Foreign Language Teaching].

3. Hossain, R, Shaikh, P., Salam, F. (2015). Efekty 'vnist'vy'kory'stannya texnologiyi $v$ klasny'x kimnatax anglijs 'koyi movy' $v$ Uryadovy'x Pervy`nny'x Shkolax $v$ Bangladesh. [The

УДК 378.018:37.091.31

DOI: $10.36550 / 2415-7988-2020-1-189-142-147$
Effectiveness of Using Technology in English Language Classrooms in Government Primary Schools in Bangladesh].

4. Shandruk, Svitlana. (2012). Tendentsii profesiinoi pidgotovky vchyteliv u USA. 「Tendencies of professional preparation of teachers in the USA]. Kirovohrad.

5. Tafani, V. (2009). Vy `kladannya anglijs koyi movy cherez zasoby masovoyi informaciyi. [Teaching English Through Mass Media].

6. Vy'kory'stannya media u vivchenni anglijs 'koyi movy`. (1979). [The Use of the Media in English Language Teaching].

7. Webster, R. (2008). Refleksy'vna metodologiya uchasti dlya elektronnogo navchannya ta navchannya protyagom us 'ogo zhy'ttya. [A reflective and Participatory Methodology for Elearning and Life-long Learning].

Wilson, B. (1996). Shho take konstrukty 'vists 'ke seredovy shhe navchannya? [What is a constructivist learning environment?].

\section{ВІДОМОСТІ ПРО АВТОРА}

ЛИСЕНКО Людмила Олександрівна кандидат педагогічних наук, доцент, кафедри лінгводидактики та іноземних мов Центральноукраїнського державного педагогічного університету імені Володимира Винниченка.

Наукові інтереси: іншомовна комунікативна культура, інноваційні методи навчання, комунікативна компетенція.

INFORMATION ABOUT THE AUTHOR

LYSENKO Liudmyla Oleksandrivna - Ph, Associate Professor, Chair of Linguodidactics And Foreign Languages Volodymyr Vynnychenko Central Ukrainian State Pedagogical University.

Circle of scientific interests: foreign language communicative culture, innovative teaching methods, communicative competence.

Стаття надійшла до редакиії 18.07.2020 p.

\begin{abstract}
ЛЯШЕНКО Ольга Дмитрівна кандидат педагогічних наук, доцент кафедри інструментально-виконавської майстерності Інституту мистецтв Київського університету імені Бориса Грінченка ORCID:https://orcid.org/0000-0002-5840-8178 e-mall: music1951@ukr.net

БУТЕНКО Тетяна Максимівна викладач кафедри інструментально-виконавської майстерності Інституту мистецтв Київського університету імені Бориса Грінченка ORCID:https://orcid.org/0000-0002-2898-3294 e-mall: t.butenko@kubg.edu.ua
\end{abstract}

\title{
ІСТОРИЧНИЙ АНАЛІЗ ПАРАДИГМ ІННОВАЦЙ В СИСТЕМІ ОСВІТИ
}

Постановка та обгрунтування актуальності проблеми. В різні часи педагоги-новатори, для подолання кризи в системі освіти, використовували більш ефективні, як для тих часів, інформаційні та інноваційні технології навчання, педагогічні 